Edunomika - Vol. 02, No. 01 (Pebruari 2018)

\title{
PENINGKATAN HASIL BELAJAR MEMBUAT SKETS GRAFIK FUNGSI ALJABAR SEDERHANA PADA SISTEM KOORDINAT KARTESIUS MELALUI METODE COOPERATIF LEARNING JIGSAW PADA SISWA KELAS VIII F SMP NEGERI 6 SUKOHARJO SEMESTER I TAHUN PELAJARAN 2017/2018
}

\author{
Sugiyamti \\ SMP Negeri 6 Sukoharjo, Jawa Tengah \\ Email: sugiyanti@gmail.com
}

\begin{abstract}
Abstrak: Penelitian ini bertujuan untuk meningkatkan hasil belajar matematika materi membuat skets grafik fungsi aljabar sederhana pada sistem koordinat kartesius melalui model pembelajaran Cooperative Learning Jigsaw pada siswa kelas VIII F SMP Negeri 6 Sukoharjo Semester II Tahun Pelajaran 2017/2018. Metode penelitian menggunakan Penelitian Tindakan Kelas yang dilaksanakan dalam dua siklus setiap siklus terdiri dua kali pertemuan, dengan empat tahap penelitian: perencanaan, pelaksanaan, pengamatan dan refleksi. Subjek penelitian ini adalah siswa-siswi kelas VIII F SMP Negeri 6 Sukoharjo tahun ajaran 2017/2018. Dengan jumlah 20 siswa. Teknik pengumpulan data yang digunakan adalah observasi, wawancara, tes, dan dokumentasi. Analisis data yang digunakan dalam penelitian ini adalah analisis deskriptif kualitatif. Hasil penelitian ini adalah meningkatkan hasil belajar matematika materi membuat skets grafik fungsi aljabar sederhana pada sistem koordinat kartesius. Hal ini dibuktikan dengan peningkatan hasil belajar siswa pada siklus I siswa yang berhasil mendapat nilai KKM, dari siklus awal hanya 11 siswa atau 55\% meningkat menjadi 14 siswa atau 70\% atau terdapat peningkatan sebesar 15\%. Sedangkan pada siklus II meningkat menjadi 17 siswa yang mendapat nilai di atas KKM atau $85 \%$ atau terdapat peningkatan sebesar $15 \%$ dari sebelumnya atau mengawali peningkatan 30\% dari siklus awal ke siklus II. Berdasarkan hasil penelitian ini dapat disimpulkan bahwa dengan penerapan model pembelajaran Cooperatif Learning Jigsaw dapat meningkatkan hasil belajar matematika materi membuat skets grafik fungsi aljabar sederhana pada sistem koordinat kartesius pada siswa kelas VIII F SMP Negeri 6 Sukoharjo Tahun Pelajaran 2017/2018.
\end{abstract}

Kata Kunci: hasil belajar, matematika, skets grafik fungsi aljabar sederhana pada sistem koordinat kartesius, Jigsaw

\begin{abstract}
This study aims to improve the learning outcomes of mathematics material to sketch the graph of simple algebraic functions on Cartesian coordinate system through Cooperative Learning Jigsaw learning model on VIII F students of SMP Negeri 6 Sukoharjo Semester II Lesson Year 2017/2018. The research method using Classroom Action Research which is carried out in two cycles each cycle consists of two meetings, with four stages of research: planning, implementation, observation and reflection. The subject of this research is the students of class VIII F SMP Negeri 6 Sukoharjo academic year 2017/2018. With a total of 20 students. Data collection techniques used are observation, interviews, tests, and documentation. Data analysis used in this research is descriptive qualitative analysis. The result of this research is to improve the result of learning mathematics material to sketch the graph of simple algebra function on cartesian coordinate system. This is evidenced by the


increase in student learning outcomes in the first cycle of students who managed to get KKM scores, from the initial cycle only 11 students or $55 \%$ increased to 14 students or $70 \%$ or an increase of $15 \%$. While in the second cycle increased to 17 students who scored above the KKM or $85 \%$ or an increase of $15 \%$ from the previous or initiate a $30 \%$ increase from the early cycle to cycle II. Based on the results of this study can be concluded that with the implementation of Cooperative Learning Jigsaw learning model can improve the learning outcomes of mathematics material to make sketches of simple algebraic functions on cartesian coordinate system in students of class VIII F SMP Negeri 6 Sukoharjo Lesson $2017 / 2018$.

Keywords: learning outcomes, mathematics, graphs sketches of simple algebra functions on Cartesian coordinate system, Jigsaw

\section{PENDAHULUAN}

Matematika merupakan mata pelajaran yang tidak asing lagi bagi kita sermua, karena mata pelajaran ini dipelajari disetiap jenjang pendidikan mulai dari SD, SMP, SMA bahkan sampai jenjang perguruan tinggi. Selain itu matematika sangat membantu serta sangat dibutuhkan pada bidang studi atau ilmu-ilmu yang lain (Samsarif 2009). Istilah Matematika sendiri berasal dari bahasa Yunani, mathein atau manthenien yang memiliki arti atau makna mempelajari. Kata matematika diduga sangat erat hubungannya dengan kata Sangsekerta, medha atau bahkan kata widya yang memiliki arti kepandaian, ketahuan atau intelegensia (Sri Subariah, 2006:1).

Dengan demikian, penyampaian mata pelajaran matematika ini terutama pada dunia pendidikan baik non formal, terlebih lagi pendidikan formal dengan penggunaan metode yang tepat bagi para siswa dapat menghasilkan hasil pembelajaran yang semakin baik, sehingga akan diperoleh generasi bangsa yang cerdas, karena matematika menjadi fondasi dalam berbagai disiplin atau bidang ilmu yang ada dan bermacam-macam tersebut. Tetapi sebaliknya jika metodenya tidak tepat para siswa akan merasa pobia atau takut dengan mata pelajaran ini.

Pendidikan menjadi motor penggerak bagi keberlangsungan sumber daya manusia yang handal suatu negara dan bangsa, karena pendidikan merupakan cara terbaik untuk meningkatkan kualitas sumber daya manusia suatu bangsa (Tho'in, 2017: 162). Sehingga pendidikan menjadi suatu aspek kehidupan yang sangat mendasar bagi pembangunan bangsa.

Pendidikan merupakan suatu aspek kehidupan yang sangat mendasar bagi pembangunan bangsa. Penyelenggaraan pendidikan di sekolah melibatkan guru sebagai pendidik dan siswa sebagai peserta didik. Hal tersebut diwujudkan dengan adanya interaksi belajar mengajar atau proses pembelajaran. Proses pembelajaran yang dilakukan oleh banyak tenaga pendidik saat ini cenderung pada pencapaian target materi kurikulum atau lebih mementingkan pada penghafalan konsep bukan pada pemahaman. Hal ini dapat dilihat dari kegiatan pembelajaran di dalam kelas yang selalu didominasi oleh guru. Dalam 
penyampaian materi, biasanya guru menggunakan model atau metode ceramah, di mana siswa hanya duduk, mencatat, dan mendengarkan apa yang disampaikannya dan sedikit peluang bagi siswa untuk bertanya atau berinteraksi secara aktif.

Pembelajaran biasanya hanya disampaikan secara konvensional, dimana guru yang berperan aktif, sementara siswa dalam kondisi yang sebaliknya yaitu cenderung pasif. Sikap siswa yang pasif dapat mengurangi keterlibatannya dalam mengikuti proses pembelajaran yang dapat mengakibatkan turunnya minat siswa dalam mengikuti proses pembelajaran.

Masalah lain yang muncul adalah rendahnya kemampuan sosial antar siswa. Rendahnya rasa sosial ini akan menimbulkan sifat individualisme pada diri siswa. Hal ini sangat tidak baik jika terus menerus ada di dalam diri siswa. Oleh karena itu, guru harus berperan aktif untuk menumbuhkan rasa sosial di antara siswa. Karena dengan tingginya kemampuan sosial yang dimiliki, para siswa akan lebih mudah berbaur di dalam lingkungan hidupnya.

Dalam hal lain yang dapat dikatakan masalah adalah kurangnya rasa percaya diri dalam diri siswa untuk mengemukakan pendapat dan berbicara di depan umum. Banyak siswa yang lebih memilih untuk memendam pendapatnya selama proses pembelajaran. Sebagai pengajar, guru harus membantu siswa menggali kepercayaan diri mereka. Karena dengan adanya rasa percaya diri, siswa akan lebih yakin untuk berbicara di hadapan orang.

Hasil belajar siswa sangat dipengaruhi oleh kualitas pembelajaran yang dilaksanakan di sekolah. Salah satu yang menentukan kualitas pembelajaran adalah penggunaan model pembelajaran yang tepat dengan materi yang diajarkan. Pada kenyataannya banyak sekolah yang kurang memperlihatkan penggunaan model pembelajaran dalam setiap penampilan mengajar.

Dengan demikian, suasana pembelajaran menjadi tidak kondusif sehingga siswa menjadi pasif. Kenyataan ini berlaku untuk semua mata pelajaran termasuk mata pelajaran matematika. Matematika merupakan ilmu pengetahuan yang mempelajari struktur yang abstrak dan pola hubungan yang ada di dalamnya (Sri Subariah, 2006:1). Dienes (dalam Ruseffendi, 1988: 160) mengatakan bahwa matematika adalah ilmu seni kreatif. Oleh karena itu, matematika harus dipelajari dan diajarkan sebagai ilmu seni. Sedangkan Kitcher (dalam Jackson, 1992: 753) lebih menfokuskan perhatiannya kepada komponen dalam kegiatan matematika. Dia mengklaim bahwa matematika terdiri atas komponen-komponen: (1) bahasa (language) yang dijalankan oleh para matematikawan, (2) pernyataan (statements) yang digunakan oleh para matematikawan, (3) pertanyaan (questions) penting yang hingga saat ini belum terpecahkan, (4) alasan (reasonings) yang digunakan untuk menjelaskan pernyataan, dan (5) ide matematika itu sendiri. Bahkan secara lebih luas matematika dipandang sebagai the science of pattern (Steen dalam Romberg, 1992: 754). Sejalan dengan kedua pandangan di atas, Sujono (1988: 5) mengemukakan beberapa pengertian matematika. Di antaranya, matematika diartikan sebagai cabang ilmu pengetahuan yang eksak dan terorganisasi secara sistematik. Selain itu, matematika merupakan ilmu pengetahuan tentang penalaran yang logik dan masalah yang berhubungan dengan bilangan. Bahkan dia mengartikan matematika sebagai ilmu bantu dalam mengiterpretasikan berbagai ide dan 
kesimpulan. Pengertian matematika sebagai ilmu tentang struktur yang terorganisir juga dikemukakan oleh Ruseffendi (1988: 261). Dari sisi abstaraksi matematika, Newman (dalam, Jackson, 1992: 755) melihat tiga ciri utama matematika, yaitu; (1) matematika disajikan dalam pola yang lebih ketat, (2) matematika berkembang dan digunakan lebih luas dari pada ilmu-ilmu lain, dan (3) matematika lebih terkonsentrasi pada konsep.

Berdasarkan pendapat di atas dapat disimpulkan bahwa matematika berkaitan dengan konsep-konsep abstrak, sehingga pemahamannya membutuhkan daya nalar yang tinggi, dibutuhkan ketekunan, keuletan, perhatian dan motivasi yang tinggi untuk dapat memahami materi pelajaran matematika.

Upaya peningkatan prestasi belajar siswa tidak terlepas dari berbagai faktor yang mempengaruhinya. Dalam hal ini, diperlukan guru kreatif yang dapat membuat pembelajaran menjadi lebih menarik dan disukai oleh pesertadidik. Suasana kelas perlu direncanakan dan dibangun sedemikian rupa dengan menggunakan model pembelajaran yang tepat agar siswa dapat memperoleh kesempatan untuk berinteraksi satu sama lain sehingga pada gilirannya dapat diperoleh prestasi belajar yang optimal. Untuk itu perlu disadari oleh guru bahwa dalam melaksanakan pembelajaran perlu pula diupayakan pembelajaran yang bersifat membangun dan memberikan pengalaman terhadap materimateri yang diberikan.

Keterbatasan waktu yang tersedia menyebabkan guru mengejar target pencapaian kurikulum memilih jalan yang termudah untuk menginformasikan fakta dan konsep, yaitu melalui model ceramah kemudian latihan soal dan siswa memperhatikan penjelasan guru tanpa melakukan aktivitas sehingga siswa pasif. Guru dalam mengajarkan matematika khususnya sub pokok bahasan membuat skets grafik fungsi aljabar sederhana pada sistem koordinat kartesius kepada siswa kurang melibatkan siswa secara aktif dalam interaksi belajar mengajar sehingga siswa kurang termotivasi dalam belajar. Guru juga kurang melibatkan lingkungan sebagai media sehingga siswa kurang mengenal lingkungan dan tidak dapat memperoleh pemahaman yang berarti. Disaat proses belajar mengajar berlangsung, guru kurang menggunakan model pembelajaran yang bervariasi sehingga hal tersebut dapat menyebabkan siswa jenuh dan kurang aktif. Guru beranggapan sulit menerapkan model pembelajaran misalnya untuk materi mata pelajaran matematika.

Penggunaan berbagai macam model pembelajaran dapat memakan waktu yang lebih lama sementara waktu mengajarnya terbatas. Guru juga jarang sekali menggunakan pendekatan pembelajaran ketika sedang mengajarkan materi pelajaran matematika. Terkait belum optimalnya proses pembelajaran matematika di kelas VIII F SMP Negeri 6 Sukoharjo, maka peneliti berupaya untuk menerapkan model pembelajaran Cooperative Learning Jigsaw sebagai salah satu alternatif pembelajaran bermakna yang bermuara pada pembelajaran yang aktif, kreatif, efektif dan menyenangkan.

Teori yang melandasi pembelajaran kooperatif jigsaw adalah teori konstruktivitas. Pada dasarnya pendekatan teori konstruktifisme dalam belajar adalah suatu pendekatan di mana siswa secara individu menemukan dan mentransformasikan informasi yang kompleks, 
memeriksa informasi sesuai dengan ketentuan dan merivisinya jika perlu (Soejadi dalam teti sobri, 2006.15).

Secara etimologi Jigsaw berasal dari bahasa Inggris yaitu gergaji ukur dan ada juga yang menyebut dengan istilah Fuzzle, yaitu sebuah teka-teki yang menyusun potongan gambar. Pembelajaran kooperatif model Jigsaw, mengambil pola cara bekerja sebuah gergaji ( jigsaw ), yaitu siswa melakukan sesuatu kegiatan belajar dengan cara bekerja sama dengan siswa lain untuk mencapai tujuan bersama.

\section{KAJIAN TEORI}

\section{Teori Hasil Belajar Siswa}

Menurut R. Gagne seperti yang dikutip oleh Slameto (2000:78) memberikan dua definisi belajar, yaitu belajar adalah suatu proses untuk memperoleh motivasi dalam pengetahuan, keterampilan, kebiasaan, dan tingkah laku. Belajar adalah penguasaan pengetahuan atau keterampilan yang diperoleh dari instruksi. Menurut Skinner yang dikutip oleh Dimyati dan Mudjiono (2006:93) bahwa belajar merupakan hubungan antara stimulus dan respon yang tercipta melalui proses tingkah laku. M. Sobry Sutikno (2010:35) mengemukakan belajar merupakan suatu proses usaha yang dilakukan oleh seseorang untuk memperoleh suatu perubahan yang baru sebagai hasil pengalamannya sendiri dalam interaksi dengan lingkungannya.

Berdasarkan beberapa pengertian di atas maka dapat penulis simpulkan bahwa belajar adalah perubahan serta peningkatan kualitas dan kuantitas tingkah laku seseorang di berbagai bidang yang terjadi akibat interaksi terus menerus dengan lingkungannya.

Hasil belajar siswa menurut W. Winkel (2004:82) adalah keberhasilan yang dicapai oleh siswa, yakni prestasi belajar siswa di sekolah yang mewujudkan dalam bentuk angka. Hasil belajar adalah pola-pola perbuatan, nilai-nilai, pengertian-pengertian, sikap-sikap, apresiasi dan keterampilan-keterampilan (Suprijono, 2011:5). Hasil belajar adalah hasil yang dicapai dalam bentuk angka atau skor setelah tes hasil belajar pada setiap akhir pembelajaran (Dimyati dan Mujiono, 2006:24).

Definisi di atas dapat disimpulkan bahwa hasil belajar adalah prestasi belajar yang dicapai siswa dalam proses kegiatan belajar mengajar dengan membawa suatu perubahan dan pembentukan tingkah laku seseorang. Untuk menyatakan bahwa suatu proses belajar dapat dikatakan berhasil, setiap guru memiliki pandangan masing-masing sejalan dengan filsafatnya. Namun untuk menyamakan persepsi sebaiknya kita berpedoman pada kurikulum yang berlaku saat ini yang telah disempurnakan, antara lain bahwa suatu proses belajar mengajar tentang suatu bahan pembelajaran dinyatakan berhasil apabila tujuan pembelajaran khususnya dapat dicapai.

Dalam rangka mengetahui tercapai tidaknya tujuan pembelajaran khusus, guru perlu mengadakan tes formatif pada setiap menyajikan suatu bahasan kepada siswa. Penilaian formatif ini untuk mengetahui sejauh mana siswa telah menguasai tujuan pembelajaran khusus yang ingin dicapai. Fungsi penelitian ini adalah untuk memberikan umpan balik pada guru dalam rangka memperbaiki proses belajar mengajar dan melaksanakan program 
remedial bagi siswa yang belum berhasil. Karena itulah, suatu proses belajar mengajar dinyatakan berhasil apabila hasilnya memenuhi tujuan pembelajaran khusus dari bahan tersebut.

Hasil belajar yang dicapai oleh siswa di sekolah merupakan salah satu ukuran terhadap penguasaan materi pelajaran yang disampaikan. Peran guru dalam menyampaikan materi pelajaran dapat mempengaruhi hasil belajar siswa. Faktor-faktor yang mempengaruhi hasil belajar siswa penting sekali untuk diketahui, artinya dalam rangka membantu siswa mencapai hasil belajar yang seoptimal mungkin.

Hasil belajar yang dicapai siswa dipengaruhi oleh dua faktor baik yang bersifat mendorong atau menghambat, demikian pula dalam belajar. Faktor yang mempengaruhi prestasi atau hasil belajar siswa yakni faktor dari dalam diri siswa (interen) dan faktor yang datang dari luar (eksteren). Ahmadi (1998:72) mengemukakan untuk mencapai prestasi belajar siswa sebagaimana yang diharapkan, maka perlu diperhatikan beberapa faktor yang mempengaruhinya antara lain faktor yang terdapat dalam diri siswa (faktor intern) dan faktor yang berasal dari luar diri siswa (faktor ekstern).

\section{Matematika}

Istilah Matematika berasal dari bahasa Yunani, mathein atau manthenien yang artinya mempelajari. Kata matematika diduga erat hubungannya dengan kata Sangsekerta, medha atau widya yang artinya kepandaian, ketahuan atau intelegensia (Sri Subariah, 2006:1).

Matematika adalah ilmu yang mempelajari tentang besaran, struktur, bangun ruang, dan perubahan-perubahan yang pada suatu bilangan. Matematika berasal dari bahasa Yunani Mathematikos yang artinya ilmu pasti. Dalam bahasa belanda matematika di sebut sebagai Wiskunde yang artinya ilmu tentang belajar. Dalam kamus besar bahasa Indonesia, definisi matematika adalah ilmu tentang bilangan dan segala sesuatu yang berhubungan dengannya yang mencangkup segala bentuk prosedur operasional yang digunakan dalam menyelesaikan masalah mengenai bilangan. Seorang yang ahli dalam bidang matematika di sebut sebagai Matematikawan atau matematikus. Segala hal yang bersangkutan dan berhubungan dengan matematika di sebut sebagai matematis. Matematis juga di gunakan untuk menyebut sesuatu secara sangat pasti dan sangat tepat.

Matematika merupakan salah satu ilmu yang banyak di manfaatkan dalam kehidupan sehari-hari. Baik secara umum maupun secara khusus. Secara umum matematika di gunakan dalam transaksi perdangangan, pertukangan, dll. Hampir di setiap aspek kehidupan ilmu matematika yang di terapkan. Karena itu matematika mendapat julukan sebagai ratu segala ilmu. Matematika juga mempunyai banyak kelebihan dibanding ilmu pengetahuan lain. Selain sifatnya yang fleksible dan dinamis, matematika juga selalu dapat mengimbangi perkembangan zaman. Terutama di masa sekarang ketika segala sesuatu dapat di lakukan dengan komputer. Matematika menjadi salah satu bahasa program yang efektif dan efisien.

Matematika merupakan ilmu pengetahuan yang mempelajari struktur yang abstrak dan pola hubungan yang ada di dalamnya (Sri Subariah, 2006:1). Dienes (dalam Ruseffendi, 1988: 160) mengatakan bahwa matematika adalah ilmu seni kreatif. Oleh karena itu, 
matematika harus dipelajari dan diajarkan sebagai ilmu seni. Sedangkan Kitcher (dalam Jackson, 1992: 753) lebih menfokuskan perhatiannya kepada komponen dalam kegiatan matematika. Dia mengklaim bahwa matematika terdiri atas komponen-komponen: (1) bahasa (language) yang dijalankan oleh para matematikawan, (2) pernyataan (statements) yang digunakan oleh para matematikawan, (3) pertanyaan (questions) penting yang hingga saat ini belum terpecahkan, (4) alasan (reasonings) yang digunakan untuk menjelaskan pernyataan, dan (5) ide matematika itu sendiri. Bahkan secara lebih luas matematika dipandang sebagai the science of pattern (Steen dalam Romberg, 1992: 754). Sejalan dengan kedua pandangan di atas, Sujono (1988: 5) mengemukakan beberapa pengertian matematika. Di antaranya, matematika diartikan sebagai cabang ilmu pengetahuan yang eksak dan terorganisasi secara sistematik. Selain itu, matematika merupakan ilmu pengetahuan tentang penalaran yang logik dan masalah yang berhubungan dengan bilangan. Bahkan dia mengartikan matematika sebagai ilmu bantu dalam mengiterpretasikan berbagai ide dan kesimpulan. Pengertian matematika sebagai ilmu tentang struktur yang terorganisir juga dikemukakan oleh Ruseffendi (1988: 261). Dari sisi abstaraksi matematika, Newman (dalam, Jackson, 1992: 755) melihat tiga ciri utama matematika, yaitu; (1) matematika disajikan dalam pola yang lebih ketat, (2) matematika berkembang dan digunakan lebih luas dari pada ilmu-ilmu lain, dan (3) matematika lebih terkonsentrasi pada konsep.

Menurut Hudoyo (1988:3) pelajaran matematika berkaitan dengan konsep-konsep abstrak, sehingga pemahamannya membutuhkan daya nalar yang tinggi, dibutuhkan ketekunan, keuletan, perhatian dan motivasi yang tinggi untuk dapat memahami materi pelajaran matematika. Sedangkan menurut (Sumarmo, 2002:2) pelajaran matematika berkaitan dengan penalaran yang bersifat deduktif, materi matematika bersifat hierarkis dan terstruktur.

\section{Skets Grafik Fungsi Aljabar Sederhana Pada Sistem Koordinat Kartesius}

Suatu fungsi finyatakan dengan himpunan pasangan berurutan $\{(\mathrm{x}, \mathrm{f}(\mathrm{x}) \mid \mathrm{x} \times € \mathrm{D}\}$ dengan D sebagai domain (daerah asal) fungsi f .jika D merupakan himpunan bagian dari $R$ (himpunan bilangan real atau nyata),maka himpunan pasangan berurutan pada fungsi $\mathrm{f}$ dapat dinyatakan dengan $\{(\mathrm{x}, \mathrm{f}(\mathrm{x}) \mid \mathrm{x} \times € \mathrm{D}\}$. Pada fungsi $\mathrm{y}=\mathrm{f}(\mathrm{x})=\mathrm{x}+1$, jika variabel $\mathrm{x}$ diganti misalnya dengan 2 , maka diperoleh nilai $\mathrm{y}=\mathrm{f}(\mathrm{x})=2+1=3$.dalam hal ini, variabel y akan bergantung pada nilai variabel $x$. Contoh: Suatu persamaan fungsi $y=f(x)=2 x-1$ memiliki daerah asal $\{-$ $1,0,1,2,3\}$ tentukan daerah bayangan dan himpunan pasangan berurutannya!

Jawab: $\mathrm{y}=\mathrm{f}(\mathrm{x})=2 \mathrm{x}-1 ; \mathrm{y}=2 \mathrm{x}-1$

untuk $x=-1$, maka $y=2(-1)-1=-3$; untuk $x=0$, maka $y=2(0)-1=-1$; untuk $x=1$, maka $y=2(1)$ $` 1=1$; untuk $x=2$, maka $y=2(2)-1=3$; untuk $x=3$, maka $y=2(3)-1=5$; daerah bayangannya adalah $\{-3,-1,1,3,5\}$; himpunan pasangan berurutannya adalah $\{(-1,-3),(0,-1),(1,1)$, $(2,3),(3,5)\}$

Dari contoh diatas terlihat bahwa variabel y ditentukan oleh besar kecilnya nilai variabel $\mathrm{x}$, atau nilai fungsi di tentukan oleh besar kecilnya anggota daerah asal. Dengan demikian nilai $y$ bergantung pada nilai $x . Y=f(x)=a x+b$ 


\section{Penggunaan Model Cooperative Learning (CL) Jigsaw}

Model berasal dari Bahasa Yunani "Methodos" yang berarti cara atau jalan yang ditempuh. Fungsi model berarti sebagai alat untuk mencapai tujuan. Pengetahuan tentang model-model sangat diperlukan oleh para pendidik, karena berhasil tidaknya siswa belajar sangat bergantung kepada tepat tidaknya model mengajar yang yang digunakan oleh guru. Modelmengajar mampu membangkitkan motivasi, minat atau gairah belajar siswa bahkan mampu meningkatkan hasil belajar siswa.

Menurut Kamus Besar Bahasa Indonesia (2008:740) model adalah cara teratur yang digunakan untuk melaksanakan suatu pekerjaan agar tercapai sesuai dengan yang dikehendaki. Menurut Sudjana dalam Adang Heriawan dkk (2012:73) model mengajar adalah cara yang dipergunakan guru dalam mengadakan hubungannya dengan siswa pada saat berlangsungnya pengajaran, peranan model mengajar sebagai alat untuk menciptakan proses mengajar dan belajar.

Dari beberapa pendapat di atas dapat disimpulkan bahwa model adalah cara yang digunakan oleh seseorang dalam melaksanakan suatu pekerjaan. Dalam hal ini adalah caracara yang dilakukan oleh guru dan peserta didik dalam melaksanakan kegiatan pembelajaran sesuai dengan tujuan yang diharapkan.

Cooperative Learning adalah salah satu model pembelajaran berbasis teori belajar sosial Robert Bandura yang dipopulerkan oleh Spencer Kagan, Robert Slavin dan Johnson \& Johnson. Cooperative Learning adalah model pembelajaran yang menekankan kepada proses kerja sama dalam suatu kelompok yang biasa terdiri dari 3 sampai 5 orang siswa untuk mempelajari suatu materi akademik yang spesifik sampai tuntas. (Adang Heriawan dkk, 2012:109). Menurut Slavin dalam Isjoni (2010 : 12) Cooperative Learning adalah model pembelajaran dimana siswa belajar dan bekerja dalam kelompok-kelompok kecil secara kolaboratif yang anggotanya 4-6 orang dengan struktur kelompok heterogen. Inti dari pembelajaran kooperatif menurut Robert E.Slavin yang diterjemahkan oleh Narulita Yusron (2010: 8) "Dalam model pembelajaran kooperatif, para siswa akan duduk bersama dalam kelompok yang beranggotakan empat orang untuk menguasai materi yang disampaikan oleh guru." Menurut Johnson \& Johnson dalam Isjoni (2010:17) Cooperataive Learning adalah mengelompokkan siswa di dalam kelas ke dalam suatu kelompok kecil agar siswa dapat bekerja bersama dengan kemampuan maksimal yang mereka miliki dan mempelajari satu sama lain dalam kelompok tersebut.

Dari beberapa definisi di atas dapat disimpulkan bahwa Model Cooperatif Learning adalah salah satu model pembelajaran yang mengutamakan kerjasama kelompok dalam menyelesaikan materi pembelajaran, memecahkan masalah atau menyelesaikan sebuah tujuan. Ada beberapa model dalam model pembelajaran Cooperative Learning diantaranya adalah: Jigsaw, Student Team Achievement Division (STAD), Team Game Tornament (TGT), Number Head Together (NHT), Group Investigation, Team Assisted Individualization (TAI) 
Pembelajaran Kooperatif JIGSAW merupakan salah satu tipe pembelajaran kooperatif yang mendorong siswa aktif dan saling membantu dalam menguasai materi pelajaran untuk mencapai prestasi yang maksimal dengan cara membentuk tim ahli. Dalam model ini terdapat tahap-tahap dalam penyelenggaraannya, yaitu:

1) Pembentukan kelompok siswa yang terdiri dari 4-6 orang secara heterogen.

2) Setiap anggota dalam kelompok ditugaskan untuk mempelajari materi tertentu.

3) Setiap anggota kelompok yang mempelajari materi yang sama bertemu dalam satu kelompok baru membentuk 'Tim Ahli'. Selanjutnya materi tersebut didiskusikan, dipelajari apabila menemukan masalah dibahas bersama.

4) Setelah masing-masing perwakilan dalam tim ahli tersebut dapat menguasai materi yang ditugaskannya, kemudian masing-masing perwakilan tersebut kembali ke kelompok masing-masing atau kelompok asalnya dan mengajarkan pada temannya.

5) Masing-masing anggota tersebut saling menjelaskan kepada teman satu kelompoknya sehingga teman dalam satu kelompoknya dapat memahami materi yang ditugaskan guru.

6) Setiap kelompok mempresentasikan hasil diskusi.

7) Siswa diberi tes/kuis untuk mengetahui apakah siswa sudah dapat memahami suatu materi atau belum.

Dengan demikian melalui penyelenggaraan model Jigsaw dalam proses belajar mengajar dapat menumbuhkan tanggung jawab siswa sehingga terlibat langsung secara aktif dalam memahami suatu persoalan dan menyelesaikannya secara kelompok. Pada kegiatan ini ini keterlibatan guru dalam belajar mengajar semakin berkurang. dalam arti guru tidak lagi menjadi pusat kegiatan kelas. Guru berperan sebagai fasilitator yang mengarahkan dan memotivasi siswa untuk belajar mandiri serta menumbuhkan rasa tanggung jawab serta siswa akan merasa senang berdiskusi tentang materi pelajaran dalam kelompoknya.

Model Jigsaw sangat cocok untuk mata pelajaran matematika karena dalam IPS banyak materi menghitung, seperti yang dikemukakan oleh Isjoni (2010:58) model Jigsaw dapat digunakan secara efektif di tiap level dimana siswa telah mendapatkan keterampilan akademis dari pemahaman, membaca maupun keterampilan kelompok untuk belajar bersama, jenis materi yang paling mudah digunakan untuk pendekatan ini adalah bentuk naratif seperti ditemukan dalam literatur, penelitian sosial membaca, dan ilmu pengetahuan.

\section{METODE}

Metode penelitian menggunakan penelitian tindakan kelas (PTK) yang dilaksanakan dalam dua siklus setiap siklus terdiri dua kali pertemuan, dengan empat tahap penelitian: perencanaan, pelaksanaan, pengamatan dan refleksi. Subjek penelitian ini adalah siswa-siswi kelas VIII F SMP Negeri 6 Sukoharjo tahun ajaran 2017/2018. Dengan jumlah 20 siswa. Teknik pengumpulan data yang digunakan adalah observasi, wawancara, tes, dan dokumentasi. Analisis data yang digunakan dalam penelitian ini adalah analisis deskriptif kualitatif. 


\section{PEMBAHASAN}

Setelah peneliti melaksanakn tindakan penelitian melalui penerapan metode Jigsaw, secara empiris diperoleh data peningkatan hasil belajar matematika materi membuat skets grafik fungsi aljabar sederhana pada sistem koordinat kartesius siswa kelas VIII F SMP Negeri 6 Sukoharjo Kecamatan Sukoharjo, Kabupaten Sukoharjo semester I Tahun Pelajaran 2017/2018 dari kondisi awal, siklus I dan siklus II sebagai berikut.

Tabel 1. Peningkatan Prestasi Belajar Siswa

\begin{tabular}{|l|c|c|c|}
\hline \multicolumn{1}{|c|}{ Uraian } & Kondisi awal & Siklus I & Siklus II \\
\hline Tindakan Pembelajaran & $\begin{array}{c}\text { Belum menerapkan } \\
\text { metode Jigsaw }\end{array}$ & $\begin{array}{c}\text { Sudah menerapkan } \\
\text { metode Jigsaw }\end{array}$ & $\begin{array}{c}\text { Sudah menerapkan } \\
\text { metode Jigsaw }\end{array}$ \\
\hline Nilai terendah & 60 & 60 & 70 \\
Nilai tertinggi & 80 & 90 & 90 \\
Nilai rata-rata & 70 & 75 & 85 \\
KKM & 75 & 75 & 75 \\
Ketuntasan & 11 siswa (55\%) & 14 siswa $(70 \%)$ & 17 siswa $(85 \%)$ \\
\hline
\end{tabular}

Melalui penerapan metode Jigsaw dapat meningkatkan hasil belajar matematika materi membuat skets grafik fungsi aljabar sederhana pada sistem koordinat kartesius.

Pada kondisi awal peneliti belum menerapkan metode Jigsaw. Nilai rata-rata siswa kelas VIII F adalah 70, masih di bawah nilai KKM yang ditetapkan yaitu 75. Nilai tertinggi siswa 80, nilai terendah 60 dan jumlah siswa kelas VIII F yang mencapai nilai KKM hanya 11 siswa (55\%) dari total 20 siswa kelas VIII F SMP Negeri 6 Sukoharjo.

Pada siklus I guru peneliti sudah menerapkan metode Jigsaw dalam pembelajaran matematika materi membuat skets grafik fungsi aljabar sederhana pada sistem koordinat kartesius. Nilai rata-rata hasil belajar matematika materi membuat skets grafik fungsi aljabar sederhana pada sistem koordinat kartesius siswa kelas VIII F SMP Negeri 6 Sukoharjo adalah 75, nilai tertinggi 90 dan nilai terendah adalah 60. Sedangkan jumlah siswa yang mencapai nilai KKM sebanyak 14 siswa (70\%) dari total 20 siswa kelas VIII F SMP Negeri 6 Sukoharjo.

Pada siklus II, nilai rata-rata hasil belajar matematika materi membuat skets grafik fungsi aljabar sederhana pada sistem koordinat kartesius siswa kelas VIII F SMP Negeri 6 Sukoharjo adalah 85, nilai tertinggi 90 dan nilai terendah 70. Jumlah siswa yang mencapai nilai KKM sebanyak 17 siswa $(85 \%)$ dari total 20 siswa kelas VIII F SMP Negeri 6 Sukoharjo.

Jadi, melalui penerapan metode Jigsaw dapat meningkatkan hasil belajar matematika materi membuat skets grafik fungsi aljabar sederhana pada sistem koordinat kartesius dari kondisi awal nilai rata-rata 70 dengan ketuntasan 55\% ke kondisi akhir pada siklus II nilai rata-rata 85 dengan ketuntasan 85\% pada siswa kelas VIII F SMP Negeri 6 Sukoharjo semester I Tahun Pelajaran 2017/2018. 
Hasil tindakan secara empirik yaitu: melalui penerapan metode Cooperative Learning Jigsaw dapat meningkatkan hasil belajar matematika materi membuat skets grafik fungsi aljabar sederhana pada sistem koordinat kartesius dari kondisi awal nilai rata-rata 70 dengan ketuntasan 55\% ke kondisi akhir pada siklus II nilai rata-rata 85 dengan ketuntasan $85 \%$ pada siswa kelas VIII F SMP Negeri 6 Sukoharjo semester I Tahun Pelajaran 2017/2018.

\section{SIMPULAN}

Hipotesis menyatakan diduga melalui penerapan metode Cooperative Learning Jigsaw dapat meningkatkan hasil belajar matematika materi membuat skets grafik fungsi aljabar sederhana pada sistem koordinat kartesius pada siswa kelas VIII F SMP Negeri 6 Sukoharjo semester I Tahun Pelajaran 2017/2018.

Dari data empirik menyatakan melalui penerapan metode Cooperative Learning Jigsaw dapat meningkatkan hasil belajar matematika materi membuat skets grafik fungsi aljabar sederhana pada sistem koordinat kartesius dari kondisi awal nilai rata-rata 70 dengan ketuntasan 55\% ke kondisi akhir pada siklus II nilai rata-rata 85 dengan ketuntasan $85 \%$ pada siswa kelas VIII F SMP Negeri 6 Sukoharjo semester I Tahun Pelajaran 2017/2018.

Sehingga dapat disimpulkan bahwa melalui penerapan metode Cooperative Learning Jigsaw dapat meningkatkan hasil belajar matematika materi membuat skets grafik fungsi aljabar sederhana pada sistem koordinat kartesius pada siswa kelas VIII F SMP Negeri 6 Sukoharjo semester I Tahun Pelajaran 2017/2018.

\section{DAFTAR PUSTAKA}

Ahmadi, Abu. 1998. Psikologo Pendidikan. Jakarta : Rineka Cipta

Agus, Suprijono. 2011. Model Pembelajaran Kooperatif. Jakarta: Bumi Aksara

Dimyati dan Mudjiono. 2006. Belajar dan Pembelajaran. Jakarta: Rineka Cipta

Heriawan, Adang dkk. 2012. Metodologi Pembelajaran Kajian Teoritis Praktis

Hudoyo (1988), Pengembangan Kurikulum Matematika dan Pelaksanaannya di Depan Kelas. Surabaya: Usaha Nasional

Ismail 2011. Manajemen Perbankan. Jakarta: Prenada Media Group

Isjoni. 2010. Cooperative Learning Efektifitas Pembelajaran Kelompok. Bandung: Alfabeta

Kamus Besar Bahasa Indonesia. 2008. Pengertian Model.

Muhibbin Syah.1999.Psikologi Pendidikan Dengan Pendekatan Baru.Bandung:PT Remaja Rosdakarya

M. Sobry Sutikno. 2010. Strategi Belajar Mengajar Melalui Penanaman Konsep Umum \& Konsep Islami. Refika Aditama: Bandung. 
Sugiyanti / Edunomika Vol. 02 No. 01 (Pebruari 2018)

Nasution. 1995. Metode Research. Jakarta : PT. Bumi Aksara

Ngalim Purwanto. 1986. Psikologi Pendidikan. Bandung: PT Remaja Rosdakarya.

Ruseffendi (1988). Pengantar Kepada Membantu Guru Mengembangkan Kompetensinya dalam Pengajaran Matematika Untuk Meningkatkan CBSA, Bandung : Tarsito.

Slameto. 2000. Belajar dan Faktor-faktor yang mempengaruhinya. Rineka Cipta,Jakarta

Sri Subarinah. (2006). Inovasi Pembelajaran Matematika SD. Jakarta: Depdiknas.

Sujono. (1988). Pengajaran Matematika untuk Sekolah Menengah. Jakarta: Departemen Pendidikan dan Kebudayaan Dirjen Dikti Proyek Pengembangan Lembaga Pendidikan Tenaga Kependidikan.

Sumarmo. 2003. "Indikator Kemampuan Komunikasi Matematika". http://kartiniokey.blogspot.com/2010/05/meningkatkan-kemampuankomunikasi. htm (diakses pada tanggal 29 Desember 2017).

Tho'in, M. (2017). Pembiayaan Pendidikan Melalui Sektor Zakat. Al-Amwal: Jurnal Ekonomi dan Perbankan Syari'ah, 9(2).

Winkel, W. S. 2004. Psikologi Pendidikan dan Evaluasi Belajar. Jakarta: PT. Gramedia Pustaka Utama. 